\title{
Knoellia locipacati sp. nov., from soil of the Demilitarized Zone in South Korea
}

\author{
Na-Ri Shin, Seong Woon Roh, Min-Soo Kim, Mi-Ja Jung, \\ Tae Woong Whon and Jin-Woo Bae
}

\author{
Correspondence \\ Jin-Woo Bae \\ baejw@khu.ac.kr
}

\author{
Department of Life and Nanopharmaceutical Sciences and Department of Biology, \\ Kyung Hee University, Seoul 130-701, Republic of Korea
}

\begin{abstract}
A Gram-positive, aerobic, rod- or coccus-shaped, non-motile bacterium, designated $\mathrm{DMZ1}{ }^{\top}$, was isolated from soil of the Demilitarized Zone, South Korea. Strain $\mathrm{DMZ1}{ }^{\top}$ grew optimally at $30{ }^{\circ} \mathrm{C}$, at $\mathrm{pH} 7-8$ and with $1 \%(\mathrm{w} / \mathrm{v}) \mathrm{NaCl}$. The isolate showed high $16 \mathrm{~S}$ rRNA gene sequence similarity with Knoellia aerolata $5317 \mathrm{~S}-21^{\top}(98.2 \%)$. The cell-wall sugars were glucose and ribose. The peptidoglycan amino acids were meso-diaminopimelic acid, glutamic acid and glycine. The major cellular fatty acids were iso- $C_{16: 0}$, iso- $C_{15: 0}$ and iso- $C_{14: 0}$. The polar lipids were phosphatidylethanolamine, phosphatidylinositol, diphosphatidylglycerol, phosphatidylglycerol and five unknown phospholipids. The isolate did not contain mycolic acids. The DNA $\mathrm{G}+\mathrm{C}$ content was $72.6 \mathrm{~mol} \%$. The isolate showed $<28 \%$ DNA-DNA relatedness with members of the genus Knoellia. Phylogenetic, phenotypic and genotypic analysis indicated that strain $\mathrm{DMZ1}^{\top}$ represents a novel species of the genus Knoellia, for which the name Knoellia locipacati sp. nov. is proposed. The type strain is $\mathrm{DMZ1} 1^{\top}\left(=\mathrm{KACC} 15114^{\top}=\mathrm{JCM} 17313^{\top}\right)$.
\end{abstract}

The Demilitarized Zone (DMZ) separating North and South Korea is an area where weapons are prohibited. After the Korean War, the Military Demarcation Line was established. The $4 \mathrm{~km}$-wide DMZ was formed along this line, with $2 \mathrm{~km}$ located on each side of the divide. Since the DMZ has been rigidly off limits to civilians for over 50 years, the natural ecology has been highly preserved; therefore, it has attracted much attention from ecologists worldwide.

Members of the genus Knoellia (Groth et al., 2002) are Gram-positive, aerobic, non-motile microbes that possess an A1 $\gamma$-type peptidoglycan moiety and $\mathrm{MK}-8(\mathrm{H} 4)$ as the major menaquinone. Currently, three species have been isolated from soil and air: Knoellia sinensis, K. subterranea (Groth et al., 2002) and K. aerolata (Weon et al., 2007). In this paper, we describe a novel species to accommodate strain $\mathrm{DMZ1}^{\mathrm{T}}$, which was isolated from soil during an investigation of the microbial ecology of the DMZ.

A soil sample was diluted with filtered PBS and incubated at $25{ }^{\circ} \mathrm{C}$ on trypticase soy agar (TSA; Bacto). The isolate was purified by subcultivation. All investigations were performed in triplicate. Physiological and biochemical experiments were performed at $25{ }^{\circ} \mathrm{C}$ for $48 \mathrm{~h}$ unless otherwise stated. Conditions for growth were determined in trypticase

Abbreviation: DAP, diaminopimelic acid.

The GenBank/EMBL/DDBJ accession number for the 16S rRNA gene sequence of strain $\mathrm{DMZ1}{ }^{\top}$ is $\mathrm{HQ} 171909$.

Two supplementary figures are available with the online version of this paper. soy broth (TSB; Bacto) at $4,10,15,25,30,37,45$ and $55{ }^{\circ} \mathrm{C}$, at $\mathrm{pH} 4-12$ (at intervals of one $\mathrm{pH}$ unit) by adjusting the $\mathrm{pH}$ of TSB with $10 \mathrm{mM}$ MES ( $\mathrm{pH}$ 4-6), $10 \mathrm{mM} \mathrm{N}$-tris(hydroxymethyl)methyl-3-aminopropanesulfonic acid ( $\mathrm{pH} 8-10)$ or $10 \mathrm{mM} \mathrm{Na}_{2} \mathrm{HPO}_{4}$ (pH 11-12) and with $0,1,2,3,4,5,8,10$, 12,15 and $20 \%(\mathrm{w} / \mathrm{v}) \mathrm{NaCl}$. The turbidity of each culture was determined by measuring the optical density at $600 \mathrm{~nm}$ (Synergy Mx; BioTek) after 24 h, 48 h and 7 days of incubation. Growth under anaerobic conditions was assessed in an anaerobic chamber under a $\mathrm{N}_{2} / \mathrm{H}_{2} / \mathrm{CO}_{2}(90: 5: 5)$ atmosphere at $37{ }^{\circ} \mathrm{C}$ for 7 days. The isolate grew at $10-37{ }^{\circ} \mathrm{C}$, at $\mathrm{pH}$ 6-9 and with $0-5 \%(\mathrm{w} / \mathrm{v}) \mathrm{NaCl}$. Optimal growth occurred at $30{ }^{\circ} \mathrm{C}$, at $\mathrm{pH} 7-8$ and with $1 \%(\mathrm{w} / \mathrm{v}) \mathrm{NaCl}$. Anaerobic growth was not observed. Gram-staining was performed using a Gram-staining kit (bioMérieux), according to the manufacturer's instructions. Cell morphology and Gram-staining were observed by light microscopy (Eclipse $50 i$; Nikon). The motility of the isolate was examined using semi-solid agar (Tittsler \& Sandholzer, 1936). Cells had an irregular rod or coccoid form and were Gram-positive and non-motile.

For the phylogenetic analysis, the 16S rRNA gene of the isolate was amplified by colony PCR using PCR PreMix (iNtRON Biotechnology) and four universal bacterial primers: 8F, 518R, 785F and 1492R (Baker et al., 2003; Kumar et al., 2003). After purification (QIAquick PCR Purification kit; Qiagen), sequencing of the amplification products was performed using the BigDye Terminator Cycle Sequencing Ready Reaction kit (Applied Biosystems), according to the manufacturer's instructions. The reaction 
mixtures were analysed using an automated DNA analyser (ABI Prism 3730 XL; Applied Biosystems). To obtain the complete $16 \mathrm{~S}$ rRNA gene sequence, fragments were assembled with SeqMan software (DNASTAR). A comparison of the 16S rRNA gene sequence of the isolate with those in the EzTaxon database (Chun et al., 2007) revealed that strain $\mathrm{DMZ1}^{\mathrm{T}}$ belonged to the genus Knoellia in the class Actinobacteria. The isolate had the highest levels of $16 \mathrm{~S}$ rRNA gene sequence similarity with $K$. aerolata $5317 \mathrm{~S}-21^{\mathrm{T}}$ (98.2\%), K. sinensis HKI $0119^{\mathrm{T}}$ (98.1\%) and K. subterranea HKI $0120^{\mathrm{T}}(98.1 \%)$. The multiple sequence alignment program CLUSTAL W (Thompson et al., 1994) was used to align the 16S rRNA gene sequence of the isolate with sequences exhibiting high pairwise similarity. The trimmed alignment was converted to MEGA and PHYLIP formats for analysis. The phylogenetic relationship between the isolate and closely related strains was investigated using the neighbour-joining (Saitou \& Nei, 1987), maximum-parsimony (Kluge \& Farris, 1969) and maximum-likelihood (Felsenstein, 1981) algorithms and bootstrap analysis was based on 1000, 1000 and 300 randomly selected replicates, respectively. The phylogenetic consensus tree was reconstructed using MEGA version 4 (Tamura et al., 2007) for the neighbour-joining and maximum-parsimony methods and PHYLIP (Felsenstein, 1996) for the maximum-likelihood method. The phylogenetic analysis indicated that the isolate formed a monophyletic clade in a cluster containing the members of the genus Knoellia (Fig. 1). According to the branch lengths of the phylogenetic tree, strain $\mathrm{DMZ1}^{\mathrm{T}}$ had the highest levels of $16 \mathrm{~S}$ rRNA gene sequence similarity with $K$. sinensis HKI $0119^{\mathrm{T}}(98.6 \%)$, K. aerolata $5317 \mathrm{~S}-21^{\mathrm{T}}$ $(98.3 \%)$ and K. subterranea HKI $0120^{\mathrm{T}}(98.3 \%)$.

Type strains of the three described species of the genus Knoellia were obtained from the DSMZ for use as reference strains. Assimilation of sole carbon sources and acid production from carbohydrates were examined using the API $50 \mathrm{CH}$ system (bioMerieux) with AUX and API 50 $\mathrm{CHB} / \mathrm{E}$ media, respectively, according to the manufacturer's instructions. Results were recorded after incubation at $30{ }^{\circ} \mathrm{C}$ for $72 \mathrm{~h}$. The API ZYM system (bioMérieux) was used to screen enzyme activities, according to the manufacturer's instructions. Catalase and oxidase activities were determined by bubble production with $3 \%(\mathrm{v} / \mathrm{v})$ hydrogen peroxide and indophenol blue production with $1 \%(\mathrm{w} / \mathrm{v})$ tetramethyl- $p$ phenylenediamine (bioMérieux), respectively. The results of the biochemical analysis are given in Table 1 and the species description. The isolate was catalase-positive and oxidasenegative and could be distinguished from the reference strains by assimilation of D-xylose and $\mathrm{N}$-acetylglucosamine and activities for trypsin and $\beta$-galactosidase.

Chemotaxonomic analysis was performed using cell biomass prepared at $25{ }^{\circ} \mathrm{C}$ for $72 \mathrm{~h}$ on R2A agar (Difco). Cell-wall sugars were extracted as described by Schleifer \& Kandler (1972) and hydrolysed using $0.5 \mathrm{M} \mathrm{H}_{2} \mathrm{SO}_{4}$ at $95{ }^{\circ} \mathrm{C}$ for $2 \mathrm{~h}$. The cell-wall sugars and standard sugars (Schön \& Groth, 2006) were separated on a cellulose TLC plate (Merck) and developed twice with ethyl acetate/pyridine/water (100:35: $25, \mathrm{v} / \mathrm{v})$. Sugars were detected by spraying with anilinephthalate spray reagent. For analysis of the cell-wall peptidoglycan amino acids, purified peptidoglycan hydrolysates $\left(6 \mathrm{M} \mathrm{HCl}, 121{ }^{\circ} \mathrm{C}, 15 \mathrm{~min}\right)$ were analysed using one-dimensional TLC on a cellulose TLC plate, according to the method of Bousfield et al. (1985). LL- and meso-diaminopimelic acid (DAP), 2,4-diaminobutyric acid, glutamic acid, glycine, alanine, lysine, threonine and ornithine were used as standards. The whole cell-wall hydrolysates of strain $\mathrm{DMZ1}^{\mathrm{T}}$ possessed glucose and ribose (Supplementary Fig. S1, available in IJSEM Online), mesoDAP, glutamic acid and glycine. Diagnostic cell-wall sugars have rarely been detected previously in the reference strains; however, two or more sugar components of the cell wall were detected in the isolate and the reference strains in this study.

Cellular fatty acids were obtained as described by the Sherlock Microbial Identification System (MIDI). The cellular fatty acids were analysed by GC (Hewlett Packard 6890) and identified using the TSBA 40 database in the Microbial Identification software package (Sasser, 1990). The major cellular fatty acids of the isolate were iso- $\mathrm{C}_{16: 0}$ $(32.6 \%)$, iso- $\mathrm{C}_{15: 0}(12.6 \%)$ and iso- $\mathrm{C}_{14: 0}(10.6 \%)$. The cellular fatty acid compositions of the isolate and the reference strains are compared in Table 2. Polar lipids were extracted by the method described by Xin et al. (2000), separated using two-dimensional TLC on a silica gel plate

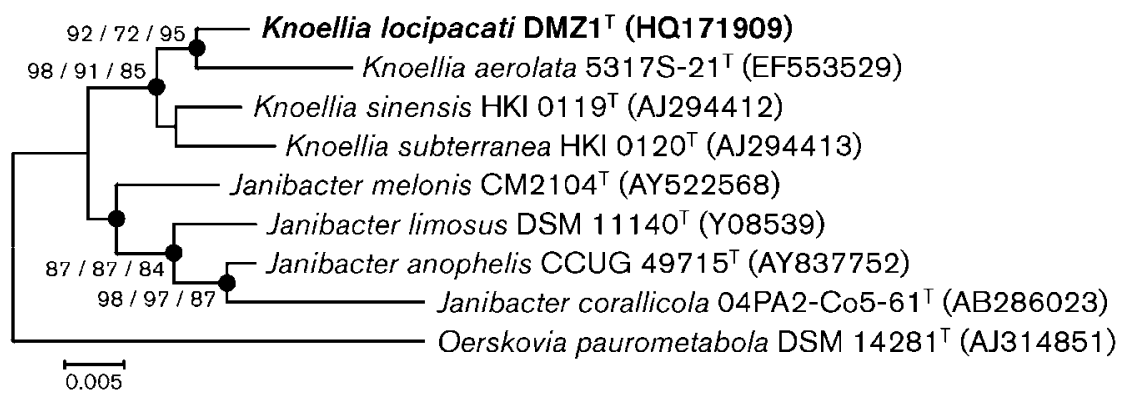

Fig. 1. Phylogenetic consensus tree based on 16S rRNA gene sequences showing the position of strain $\mathrm{DMZ} 1^{\top}$ with its closest neighbours. Bootstrap values $(>70 \%)$ based on 1000,1000 and 300 replicates for the neighbour-joining, maximum-parsimony and maximum-likelihood algorithms, respectively, are shown at branch nodes. Filled circles indicate that the corresponding nodes were recovered in the tree generated with all three algorithms. Bar, 0.005 substitutions per nucleotide. 
Table 1. Differential biochemical characteristics of strain $\mathrm{DMZ1}{ }^{\top}$ and the type strains of closely related species in the genus Knoellia

Strains: 1 , Knoellia locipacati sp. nov. DMZ1 ${ }^{\mathrm{T}} ; 2, K$. aerolata DSM $18566^{\mathrm{T}} ; 3$, K. sinensis DSM $12331^{\mathrm{T}} ; 4$, K. subterranea DSM $12332^{\mathrm{T}}$. All data were taken from this study. All strains assimilate D-glucose, Dmannose, aesculin, cellobiose, maltose, sucrose, trehalose, starch and turanose, produce acid from D-ribose, D-glucose, aesculin, starch and glycogen and produce esterase lipase (C8), leucine arylamidase, valine arylamidase and naphthol-AS-BI-phosphohydrolase. +, Positive; w, weakly positive; - , negative.

\begin{tabular}{|c|c|c|c|c|}
\hline Characteristic & 1 & 2 & 3 & 4 \\
\hline \multicolumn{5}{|c|}{ Assimilation of (API $50 \mathrm{CH}$ ). } \\
\hline Glycerol & - & - & - & $\mathrm{w}$ \\
\hline D-Ribose & - & - & $\mathrm{w}$ & $\mathrm{w}$ \\
\hline D-Xylose & $\mathrm{w}$ & - & - & - \\
\hline D-Galactose & $\mathrm{w}$ & $\mathrm{w}$ & $\mathrm{w}$ & + \\
\hline D-Fructose & + & + & - & + \\
\hline Inositol & - & $\mathrm{w}$ & - & - \\
\hline D-Mannitol & + & + & - & + \\
\hline D-Sorbitol & $\mathrm{w}$ & + & - & $\mathrm{w}$ \\
\hline$N$-Acetylglucosamine & - & + & $\mathrm{w}$ & + \\
\hline Salicin & - & - & - & $\mathrm{w}$ \\
\hline Lactose & - & - & - & $\mathrm{w}$ \\
\hline Inulin & - & + & - & - \\
\hline Melezitose & $\mathrm{w}$ & + & - & - \\
\hline Raffinose & - & $\mathrm{w}$ & - & - \\
\hline Xylitol & - & + & - & $\mathrm{w}$ \\
\hline D-Lyxose & + & + & - & $\mathrm{w}$ \\
\hline D-Arabitol & + & + & - & $\mathrm{w}$ \\
\hline Gluconate & - & + & - & - \\
\hline \multicolumn{5}{|c|}{ Acid production from (API $50 \mathrm{CHB}$ ): } \\
\hline D-Arabinose & $\mathrm{w}$ & $\mathrm{w}$ & - & - \\
\hline D-Xylose & $\mathrm{w}$ & $\mathrm{w}$ & - & - \\
\hline L-Xylose & $\mathrm{w}$ & $\mathrm{w}$ & - & - \\
\hline D-Galactose & + & $\mathrm{w}$ & w & + \\
\hline D-Fructose & + & + & $\mathrm{w}$ & + \\
\hline D-Mannose & + & + & $\mathrm{w}$ & + \\
\hline L-Sorbose & - & $\mathrm{w}$ & - & - \\
\hline Inositol & $\mathrm{w}$ & $\mathrm{w}$ & - & - \\
\hline D-Mannitol & $\mathrm{w}$ & + & - & - \\
\hline D-Sorbitol & $\mathrm{w}$ & + & - & - \\
\hline Methyl $\alpha$-D-glucoside & $\mathrm{w}$ & $\mathrm{w}$ & - & - \\
\hline $\mathrm{N}$-Acetylglucosamine & - & $\mathrm{w}$ & - & - \\
\hline Salicin & + & + & $\mathrm{w}$ & + \\
\hline Cellobiose & + & + & $\mathrm{w}$ & + \\
\hline Maltose & + & + & $\mathrm{w}$ & $\mathrm{w}$ \\
\hline Lactose & $\mathrm{w}$ & + & $\mathrm{w}$ & $\mathrm{w}$ \\
\hline Sucrose & + & + & $\mathrm{w}$ & $\mathrm{w}$ \\
\hline Trehalose & + & + & $\mathrm{w}$ & $\mathrm{w}$ \\
\hline Inulin & - & + & - & - \\
\hline Melezitose & $\mathrm{w}$ & - & $\mathrm{w}$ & - \\
\hline Raffinose & - & + & - & - \\
\hline Xylitol & $\mathrm{w}$ & w & - & - \\
\hline Gentiobiose & $\mathrm{w}$ & w & $\mathrm{w}$ & - \\
\hline Turanose & + & + & + & w \\
\hline D-Lyxose & + & + & - & $\mathrm{w}$ \\
\hline
\end{tabular}

Table 1. cont.

\begin{tabular}{|lcccc|}
\hline Characteristic & $\mathbf{1}$ & $\mathbf{2}$ & $\mathbf{3}$ & $\mathbf{4}$ \\
\hline D-Arabitol & $\mathrm{w}$ & $\mathrm{w}$ & - & - \\
Gluconate & $\mathrm{W}$ & - & - & - \\
5-Ketogluconate & $\mathrm{W}$ & - & + & $\mathrm{w}$ \\
Enzyme activity (API ZYM) & & & & \\
$\quad$ Alkaline phosphatase & + & + & $\mathrm{w}$ & + \\
Esterase (C4) & + & $\mathrm{w}$ & + & + \\
Cystine arylamidase & - & - & $\mathrm{w}$ & - \\
Trypsin & $\mathrm{w}$ & - & - & - \\
Acid phosphatase & + & - & $\mathrm{w}$ & - \\
$\beta$-Galactosidase & $\mathrm{w}$ & - & - & - \\
$\beta$-Glucuronidase & - & + & - & - \\
$\alpha$-Glucosidase & + & $\mathrm{w}$ & + & + \\
$\beta$-Glucosidase & + & $\mathrm{w}$ & $\mathrm{w}$ & + \\
\hline
\end{tabular}

(Merck) and detected using appropriate detection reagents, as described by Tindall (1990). Briefly, four spray reagents were used as follows: molybdatophosphoric acid for total lipids, ninhydrin reagent for amino-containing lipids, Zinzadze

Table 2. Cellular fatty acid contents of strain $\mathrm{DMZ1}{ }^{\top}$ and the type strains of closely related species in the genus Knoellia

Strains: 1, Knoellia locipacati sp. nov. DMZ1 ${ }^{\mathrm{T}} ; 2, K$. aerolata DSM $18566^{\mathrm{T}} ; 3$, K. sinensis DSM $12331^{\mathrm{T}} ; 4$, K. subterranea DSM $12332^{\mathrm{T}}$. All data were taken from this study after culture on R2A agar at $25{ }^{\circ} \mathrm{C}$ for $72 \mathrm{~h}$. Values are percentages of the total fatty acids. tr, Trace $(<1.0 \%) ;-$, not detected.

\begin{tabular}{|c|c|c|c|c|}
\hline Fatty acid (\%) & 1 & 2 & 3 & 4 \\
\hline iso- $\mathrm{C}_{13: 0}$ & - & $\operatorname{tr}$ & 1.1 & - \\
\hline $\mathrm{C}_{14: 0}$ & $\operatorname{tr}$ & 5.4 & 1.4 & 1.1 \\
\hline iso- $\mathrm{C}_{14: 0}$ & 10.6 & 4.5 & 3.9 & 10.8 \\
\hline $\mathrm{C}_{14: 1} \omega 5 c$ & 2.1 & 1.6 & 1.2 & 1.0 \\
\hline $\mathrm{C}_{15: 0}$ & 3.9 & 6.7 & 1.4 & 2.3 \\
\hline anteiso- $\mathrm{C}_{15: 0}$ & - & - & 2.0 & 4.1 \\
\hline iso- $\mathrm{C}_{15: 0}$ & 12.6 & 10.5 & 20.4 & 13.0 \\
\hline $\mathrm{C}_{16: 0}$ & 1.4 & 14.4 & 10.0 & 6.5 \\
\hline iso- $\mathrm{C}_{16: 0}$ & 32.6 & 9.2 & 15.6 & 25.2 \\
\hline 10-Methyl $C_{16: 0}$ & 2.8 & - & - & - \\
\hline iso- $\mathrm{C}_{16: 1} \mathrm{H}$ & 1.1 & - & - & - \\
\hline $\mathrm{C}_{17: 0}$ & 6.1 & 11.5 & 4.6 & 7.0 \\
\hline anteiso- $\mathrm{C}_{17: 0}$ & - & - & 2.1 & 3.3 \\
\hline iso- $\mathrm{C}_{17: 0}$ & - & - & 17.8 & 7.0 \\
\hline iso- $\mathrm{C}_{17: 0} 3-\mathrm{OH}$ & - & 3.4 & 1.9 & - \\
\hline 10-Methyl $\mathrm{C}_{17: 0}$ & 9.8 & - & $\operatorname{tr}$ & 2.3 \\
\hline $\mathrm{C}_{17: 0} 3-\mathrm{OH}$ & 4.1 & - & - & $\operatorname{tr}$ \\
\hline $\mathrm{C}_{17: 1} \omega 8 c$ & 9.4 & 11.3 & - & 1.7 \\
\hline iso- $\mathrm{C}_{17: 1} \omega 9 c$ & - & - & 5.2 & 4.1 \\
\hline $\mathrm{C}_{18: 0}$ & - & 5.8 & 3.1 & 2.1 \\
\hline iso- $\mathrm{C}_{18: 0}$ & - & - & 2.4 & 4.2 \\
\hline $\mathrm{C}_{18: 1} \omega 7 c$ & - & 6.8 & 2.1 & $\operatorname{tr}$ \\
\hline $\mathrm{C}_{18: 1} \omega 9 c$ & $\operatorname{tr}$ & 5.4 & 1.6 & 1.3 \\
\hline
\end{tabular}


Table 3. DNA-DNA hybridization values between strain $\mathrm{DMZ1}{ }^{\top}$ and the type strains of closely related species

\begin{tabular}{|c|c|c|c|c|}
\hline \multirow[t]{2}{*}{ Species } & \multicolumn{4}{|c|}{ DNA-DNA hybridization (\%) with: } \\
\hline & 1 & 2 & 3 & 4 \\
\hline 1. K. locipacati $\mathrm{DMZ1}^{\mathrm{T}}$ & $100 \pm 0$ & $54 \pm 5$ & $37 \pm 3$ & $20 \pm 2$ \\
\hline 2. K. aerolata DSM $18566^{\mathrm{T}}$ & $20 \pm 6$ & $100 \pm 0$ & $30 \pm 4$ & $13 \pm 2$ \\
\hline 3. K. sinensis DSM $12331^{\mathrm{T}}$ & $28 \pm 4$ & $30 \pm 6$ & $100 \pm 0$ & $16 \pm 5$ \\
\hline 4. K. subterranea DSM $12332^{\mathrm{T}}$ & $22 \pm 6$ & $40 \pm 4$ & $32 \pm 4$ & $100 \pm 0$ \\
\hline
\end{tabular}

reagent for phospholipids and $\alpha$-naphthol reagent for glycolipids. The isolate contained phosphatidylethanolamine, phosphatidylinositol, diphosphatidylglycerol, phosphatidylglycerol and five unknown phospholipids (Supplementary Fig. S2). Mycolic acids were extracted and purified according to Yano \& Saito (1972), and were detected by TLC as described by Goodfellow et al. (1976), using mycolic acid of Corynebacterium terpenotabidum IFO $14764^{\mathrm{T}}$ as a positive control. Mycolic acids were not detected. Various cell-wall chemical characteristics, including the presence of the directly cross-linked meso-DAP-containing peptidoglycan type (A1 $\gamma)$ (Schleifer \& Kandler, 1972), the polar lipid profile and the absence of mycolic acids, suggested that strain $\mathrm{DMZ1}^{\mathrm{T}}$ should be assigned to the genus Knoellia (Groth et al., 2002).

Genomic DNA extraction from the isolate and the reference strains was carried out using the method described by Rochelle et al. (1992). The G $+\mathrm{C}$ content was determined by a fluorimetric method using SYBR Gold I and a real-time PCR thermocycler (Gonzalez \& Saiz-Jimenez, 2002). Genomic DNA of Escherichia coli K-12 was used as a reference for calibration (Sambrook et al., 1989). The G $+\mathrm{C}$ content of the genomic DNA of the isolate was $72.6 \mathrm{~mol} \%$. High DNA $\mathrm{G}+\mathrm{C}$ content is a common feature of members of the genus Knoellia. To define the genetic relatedness between the isolate and the reference strains, DNA-DNA hybridization was performed at $37{ }^{\circ} \mathrm{C}$ as described previously (Bae et al., 2005; Chang et al., 2008). DNA-DNA relatedness between strain $\mathrm{DMZ1}^{\mathrm{T}}$ (as the target strain) and $K$. aerolata DSM $18566^{\mathrm{T}}$, K. sinensis DSM $12331^{\mathrm{T}}$ and $K$. subterranea DSM $12332^{\mathrm{T}}$ was $20 \pm 6,28 \pm 4$ and $22 \pm 6 \%$, respectively, and for the reciprocal experiments (strain $\mathrm{DMZ1}^{\mathrm{T}}$ as the probe) was $54 \pm 5 \%, 37 \pm 3 \%$ and $20 \pm 2 \%$, respectively (Table 3 ). On the basis that $<70 \%$ DNA-DNA relatedness indicates strain distinctness (Wayne et al., 1987), the isolate was considered to represent a novel species.

On the basis of clearly distinguished phylogenetic, phenotypic and genotypic characteristics, we demonstrate that strain $\mathrm{DMZ1}^{\mathrm{T}}$ represents a novel species of the genus Knoellia, for which the name Knoellia locipacati sp. nov. is proposed.

\section{Description of Knoellia locipacati sp. nov.}

Knoellia locipacati (lo.ci.pa.ca'ti. L. masc. n. locus a place, country region; L. adj. pacatus pacified, peaceful, quiet; N.L. gen. n. locipacati of a peaceful place).
Cells are Gram-stain-positive, obligately aerobic, irregular rods/cocci and non-motile. Colonies are circular, slightly glistening, moist, translucent, raised with entire margin and white or cream and $0.5-0.7 \mathrm{~mm}$ in diameter after 2 days on R2A agar at $30{ }^{\circ} \mathrm{C}$. Growth occurs at $10-37{ }^{\circ} \mathrm{C}$ (optimum $30{ }^{\circ} \mathrm{C}$ ), at $\mathrm{pH}$ 6-9 (optimum $\mathrm{pH} 7-8$ ) and with $0-5 \% \mathrm{NaCl}$ (optimum $1 \%$ ). With API $50 \mathrm{CH}$, assimilates D-xylose, Dgalactose, D-glucose, D-fructose, D-mannose, D-mannitol, Dsorbitol, aesculin, cellobiose, maltose, melezitose, starch, glycogen, turanose, D-lyxose and D-arabitol. With API 50 $\mathrm{CHB}$, produces acid with $\mathrm{D}$-arabinose, D-ribose, $\mathrm{D}-$ and $\mathrm{L}-$ xylose, D-galactose, D-glucose, D-fructose, D-mannose, inositol, D-mannitol, D-sorbitol, methyl $\alpha$-D-glucoside, aesculin, salicin, cellobiose, maltose, lactose, sucrose, trehalose, melezitose, starch, glycogen, xylitol, gentiobiose, turanose, D-lyxose, D-arabitol, gluconate and 5-ketogluconate. Catalasepositive and oxidase-negative. With API ZYM, positive for alkaline phosphatase, esterase (C4), esterase lipase (C8), lipase $(\mathrm{C} 14)$, leucine arylamidase, valine arylamidase, trypsin, acid phosphatase, naphthol-AS-BI-phosphohydrolase, $\beta$-galactosidase and $\alpha$ - and $\beta$-glucosidases. The cell-wall sugars are glucose and ribose. The peptidoglycan is an Al $\gamma$ type consisting of meso-DAP, glutamic acid and glycine. The main cellular fatty acids are iso- $\mathrm{C}_{16: 0}$, iso- $\mathrm{C}_{15: 0}$ and iso- $\mathrm{C}_{14: 0}$. The major polar lipids are phosphatidylethanolamine, phosphatidylinositol, diphosphatidylglycerol, phosphatidylglycerol and five unknown phospholipids. Mycolic acids are absent. The DNA G + C content of the type strain is $72.6 \mathrm{~mol} \%$.

The type strain is $\mathrm{DMZ1}^{\mathrm{T}}\left(=\mathrm{KACC} 15114^{\mathrm{T}}=\mathrm{JCM} 17313^{\mathrm{T}}\right.$ ), isolated from soil of the Demilitarized Zone in South Korea.

\section{Acknowledgements}

We thank Dr J.P. Euzéby (École Nationale Vétérinaire, France) for etymological advice.

\section{References}

Bae, J.-W., Rhee, S.-K., Park, J. R., Chung, W.-H., Nam, Y.-D., Lee, I., Kim, H. \& Park, Y.-H. (2005). Development and evaluation of genomeprobing microarrays for monitoring lactic acid bacteria. Appl Environ Microbiol 71, 8825-8835.

Baker, G. C., Smith, J. J. \& Cowan, D. A. (2003). Review and reanalysis of domain-specific $16 \mathrm{~S}$ primers. J Microbiol Methods 55, 541555. 
Bousfield, G. R., Sugino, H. \& Ward, D. N. (1985). Demonstration of a $\mathrm{COOH}$-terminal extension on equine lutropin by means of a common acid-labile bond in equine lutropin and equine chorionic gonadotropin. J Biol Chem 260, 9531-9533.

Chang, H.-W., Nam, Y.-D., Jung, M. Y., Kim, K.-H., Roh, S. W., Kim, M.-S., Jeon, C. O., Yoon, J.-H. \& Bae, J.-W. (2008). Statistical superiority of genome-probing microarrays as genomic DNA-DNA hybridization in revealing the bacterial phylogenetic relationship compared to conventional methods. J Microbiol Methods 75, 523-530.

Chun, J., Lee, J.-H., Jung, Y., Kim, M., Kim, S., Kim, B. K. \& Lim, Y.-W. (2007). EzTaxon: a web-based tool for the identification of prokaryotes based on $16 \mathrm{~S}$ ribosomal RNA gene sequences. Int J Syst Evol Microbiol 57, 2259-2261.

Felsenstein, J. (1981). Evolutionary trees from DNA sequences: a maximum likelihood approach. J Mol Evol 17, 368-376.

Felsenstein, J. (1996). Inferring phylogenies from protein sequences by parsimony, distance, and likelihood methods. Methods Enzymol 266, 418-427.

Gonzalez, J. M. \& Saiz-Jimenez, C. (2002). A fluorimetric method for the estimation of $\mathrm{G}+\mathrm{C}$ mol\% content in microorganisms by thermal denaturation temperature. Environ Microbiol 4, 770-773.

Goodfellow, M., Collins, M. D. \& Minnikin, D. E. (1976). Thinlayer chromatographic analysis of mycolic acid and other long-chain components in whole-organism methanolysates of coryneform and related taxa. J Gen Microbiol 96, 351-358.

Groth, I., Schumann, P., Schütze, B., Augsten, K. \& Stackebrandt, E. (2002). Knoellia sinensis gen. nov., sp. nov. and Knoellia subterranea sp. nov., two novel actinobacteria isolated from a cave. Int J Syst Evol Microbiol 52, 77-84.

Kluge, A. G. \& Farris, F. S. (1969). Quantitative phyletics and the evolution of anurans. Syst Zool 18, 1-32.

Kumar, P. S., Griffen, A. L., Barton, J. A., Paster, B. J., Moeschberger, M. L. \& Leys, E. J. (2003). New bacterial species associated with chronic periodontitis. J Dent Res 82, 338-344.

Rochelle, P. A., Fry, J. C., Parkes, R. J. \& Weightman, A. J. (1992). DNA extraction for $16 \mathrm{~S}$ rRNA gene analysis to determine genetic diversity in deep sediment communities. FEMS Microbiol Lett 79, 59-65.

Saitou, N. \& Nei, M. (1987). The neighbor-joining method: a new method for reconstructing phylogenetic trees. Mol Biol Evol 4, 406-425.
Sambrook, J., Fritsch, E. F. \& Maniatis, T. (1989). Molecular Cloning: a Laboratory Manual, 2nd edn. Cold Spring Harbor, NY: Cold Spring Harbor Laboratory.

Sasser, M. (1990). Identification of bacteria by gas chromatography of cellular fatty acids, MIDI Technical Note 101. Newark, DE: MIDI Inc.

Schleifer, K. H. \& Kandler, O. (1972). Peptidoglycan types of bacterial cell walls and their taxonomic implications. Bacteriol Rev 36, 407-477.

Schön, R. \& Groth, I. (2006). Practical thin layer chromatography techniques for diaminopimelic acid and whole cell sugar analyses in the classification of environmental actinomycetes. J Basic Microbiol 46, 243-249.

Tamura, K., Dudley, J., Nei, M. \& Kumar, S. (2007). MEGA4: molecular evolutionary genetics analysis (MEGA) software version 4.0. Mol Biol Evol 24, 1596-1599.

Thompson, J. D., Higgins, D. G. \& Gibson, T. J. (1994). CLUSTAL W: improving the sensitivity of progressive multiple sequence alignment through sequence weighting, position-specific gap penalties and weight matrix choice. Nucleic Acids Res 22, 4673-4680.

Tindall, B. J. (1990). Lipid composition of Halobacterium lacusprofundi. FEMS Microbiol Lett 66, 199-202.

Tittsler, R. P. \& Sandholzer, L. A. (1936). The use of semi-solid agar for the detection of bacterial motility. J Bacteriol 31, 575-580.

Wayne, L. G., Brenner, D. J., Colwell, R. R., Grimont, P. A. D., Kandler, O., Krichevsky, M. I., Moore, L. H., Moore, W. E. C., Murray, R. G. E. \& other authors (1987). International Committee on Systematic Bacteriology. Report of the ad hoc committee on reconciliation of approaches to bacterial systematics. Int J Syst Bacteriol 37, 463-464.

Weon, H.-Y., Kim, B.-Y., Schumann, P., Kroppenstedt, R. M., Noh, H.-J., Park, C.-W. \& Kwon, S.-W. (2007). Knoellia aerolata sp. nov., isolated from an air sample in Korea. Int J Syst Evol Microbiol 57, 2861-2864.

Xin, H., Itoh, T., Zhou, P., Suzuki, K., Kamekura, M. \& Nakase, T. (2000). Natrinema versiforme sp. nov., an extremely halophilic archaeon from Aibi salt lake, Xinjiang, China. Int J Syst Evol Microbiol 50, 12971303.

Yano, I. \& Saito, K. (1972). Gas chromatographic and mass spectrometric analysis of molecular species of corynomycolic acids from Corynebacterium ulcerans. FEBS Lett 23, 352-356. 